\title{
EchoGéo
}

$20 \mid 2012$

Des mobilités aux transports. Regards croisés en Afrique de l'ouest

\section{From mobilities to transport. Diverse outlooks on Western Africa}

Jérôme Lombard et Olivier Ninot

\section{(2) OpenEdition}

\section{Journals}

Édition électronique

URL : https://journals.openedition.org/echogeo/13286

DOI : 10.4000/echogeo.13286

ISSN : 1963-1197

Éditeur

Pôle de recherche pour l'organisation et la diffusion de l'information géographique (CNRS UMR 8586)

Référence électronique

Jérôme Lombard et Olivier Ninot, « From mobilities to transport. Diverse outlooks on Western Africa ", EchoGéo [En ligne], 20 | 2012, mis en ligne le 17 janvier 2013, consulté le 10 août 2021. URL : http:// journals.openedition.org/echogeo/13286; DOI : https://doi.org/10.4000/echogeo.13286

Ce document a été généré automatiquement le 10 août 2021.

EchoGéo est mis à disposition selon les termes de la licence Creative Commons Attribution - Pas d'Utilisation Commerciale - Pas de Modification 4.0 International (CC BY-NC-ND) 


\title{
From mobilities to transport. Diverse outlooks on Western Africa
}

\author{
Jérôme Lombard et Olivier Ninot
}

1 This issue of EchoGéo aims to study mobilities and transport systems in Western Africa. Our analysis is based on two factual reasons. First, on the western side of the continent, the local development of transport has been fast and has brought about an acceleration of local, regional and international flows. Secondly, the culture of engineering, which has long prevailed in the field of transport, in particular with the predominance of French expertise ${ }^{1}$, needs to be completed by a cross-disciplinary approach if we are to understand the factors that presided to the joint evolution of transport systems and mobilities in Western Africa. Things have changed and, as part of a scientific method, these systems need to be considered not only from a technical perspective but more importantly as a factor of mobility for people and goods.

\section{Transport and mobilities}

2 There is a lack of research dedicated to transport and mobilities, in spite of analyses developed in the last decade on mobile Africa (Bruijn, Van Dijk et al., 2001 ; Hahn and Klute, 2007) and on migratory movements or flows (Mansell, Prothero and Chapman, 2010). Research work looking specifically into transport systems is also incomplete: for instance, the Sitrass network's research ${ }^{2}$, or the monograph on the motorisation of African transport in the twentieth century published by J.B. Gewald, S. Luning and K. Van Walraven (2009), do not include a study of people's mobility and trade. Some of these works do however complement international institutions' research on urban transport in metropolises (Dawson and Barwell, 1993 ; Porter, 2002 ; Dimitriou and Gakenheimer, 2011), opening the way for a global understanding of mobilities.

3 Considering mobilities and transport systems as interlocked and interdependent makes sense as much from the field as from a theoretical perspective. The different types of movement that can be observed are interlocked and cause the transport systems to evolve. Equally, these systems influence the patterns and modalities of travel. The 
dispersion of African families across increasingly remote spaces is connected to the multiplication of travelling possibilities; long-distance migrations are made possible by improvements in transport infrastructure and services; in cities, residential mobility between different areas transforms urban transport, which in turn supports the growth of the suburbs, even the most remote; occasional (tourism) or professional (trade) travel benefit from the growth of air transport. Transport systems are increasingly efficient (speed, comfort, price), which makes mobilities, including in Africa, interchangeable and reversible. According to V. Kaufmann (2005), pendular travel, biresidentiality as well as long-distance and short-term travel have become more frequent and offer an alternative to other forms of mobility (migration, change of residence).

\section{Development of transport systems and growing traffic in Western Africa: perspectives and interests}

In 2011, the organization looked into two main axes of questioning: the interconnection of different forms of mobility, and the part played by transport in their everyday adaptation. These lines were examined at the European Conference of African studies in Uppsala (ECAS: www.nai.uu.se/ecas-4/conference-announcement), in a workshop dedicated to the joint study of transport and mobility in Western Africa. The workshop, held every two years in partnership with the Africa-Europe Group for Interdisciplinary Studies (AEGIS: www.aegis-eu.org), provides the opportunity for researchers to exchange views on contemporary African societies. Studies of transport systems are usually discussed at thematic or technical conferences. Our objective was to bring the study of transport to a conference targeted at specialists of the African continent who usually favour cultural, historical, anthropological and more rarely geographic approaches ${ }^{3}$.

5 Coming back to the overall theme of the conference (African Engagements: On Whose Terms?), we sought to answer the following question: "Development of transport systems and growth of circulation in Western Africa: which perspectives for whose interests?". The workshop revealed a connection between the development of transport systems, the acceleration of traffics and current developments in the economic, social, political and territorial fields. Transport and its associated mobility is not only the indicator of Western Africa's insertion into global neoliberal dynamics and a sign of the continent's place in the world (Ferguson, 2006), but also the vectors of specific constructs. This issue will seek to identify and analyse the forces that gave rise to current changes in transport and circulation systems: the economical and political interests at stake, the populations, individuals and agents affected by the traffics and their different motivations, the reconfiguration of territories. In this Western African space, we will also look at the conjunction of processes, the growth of differentiation and the combination, under different forms, of old structures and new ways of life and know-hows.

6 Three groups of texts presented in this issue refer to three contemporary trends that structure the mobilities/transport duo. The first of them is to do with the contrasts of scale that are made visible by the development of transport systems. International transport is opening up countries without an access to the sea, and transport corridors allowing for a fluid circulation along the infrastructure are being consolidated: the 
constant activity of local and national traffics reminds us of how ubiquitous road transport is and how adapted it is to demand, far ahead of rail transport which is mostly used for freight. The second trend confirms the need for local approaches that take into account the evolution of ways of life, the multiplicity of travelling modes, the insertion of urban and rural populations into a contemporary, dynamic and diverse mobility. The growth of diverse types of travel tends to stimulate transport: it introduces the need for new vehicles, new supply, new roads, with populations inventing their own transportation modes, irrigating neighbourhoods and villages according to their needs, overcoming the constraints and practical programming imposed by spatial or urbanistic systems (Di Méo, 1999: 89). Moto taxis provide a good example of this evolution. The third trend is a growing inequality. The spatial pattern of a corridor connecting two poles regardless of the space it crosses, predominant in railway transport, is now threatening to affect road transport as well, because of the ever-growing inequality in access to decent roads and services. Getting to an asphalted road remains a challenge in many West African locations, villages and urban districts, in spite of the various forms of mobility allowed by road transport. Wealthy populations are fully integrated within this mobile world because of their ability to use transport in all its forms: their way of life uses space as a territory made of networked locations. But what about the others? The issues at stake are the regulation of disparities, the balance to be achieved between individual interests, and the part played in Western Africa by governments, decentralised authorities and associations of professionals and service users.

\section{Transport corridors and main operators}

7 Economic globalization requires interconnected poles of activity and population, even located far apart; it also requires for circulation between two terminals to be fluid (Hall et al., 2010) and undisrupted by local logistical, social or political problems. The dynamics of the transport corridor accentuate the concentration of investment along a few axes, and encourage the local implantation of international logistical and transportation operators, who tend to be present at the nodes of large infrastructures and not in intermediary spaces. There is therefore a growing gap between the dynamics of international transport and the national territory.

8 Jean Debrie (The West African port system: global insertion and regional particularities) highlights the gradual transition from a rail-based system serving the entire WestAfrican territory towards a system that joins together a number of remote and isolated terminals that are only connected to the rest of the world via international transport. The competition between portuary terminals leads large logistics groups to select one or two locations from which to serve the surrounding territories via coastal navigation (ISEMAR, 2008). Abidjan seems to be emerging as Western Africa's leading transhipment port. Similarly, Lomé in Togo is seeking to make the most of its natural assets (a deep water port, halfway between Lagos and Accra) to capture part of this traffic, while consolidating its function as a transit point into its hinterland.

9 Foussata Dagnogo, Olivier Ninot and Jean-Louis Chaléard (Le chemin de fer Abidjan Niger: la vocation d'une infrastructure en question) complement J. Debrie's study by focusing on the international Abidjan/Ouagadougo rail connection. Since its privatisation in 1995 it has belonged to French group Bolloré, and its activity has been 
polarised by the transit of container trains between the port of Abidjan and the terminals of Ouagadougou (Burkina Fason) and Ferkessédougou (Ivory Coast), where they are transferred onto trucks and driven to Mali. The paper highlights the evolution of train shifts: those are not stopping any more in the numerous stations along the line which used to be poles of concentration and redistribution for local traffic. Trains increasingly connect line terminals together, to the detriment of intermediary stops which are seen by operators as not profitable enough. This spatial differentiation process also occurs in other parts of Africa, for instance on the Dakar/Bamako line ${ }^{4}$, or the one that connects Dar es Salaam (Tanzania) to Zambia (Monson, 2006).

What is at play here is the capacity of West-African transport system to satisfy an increasingly diversified demand from populations and economic operators. Railway transport, underdeveloped or neglected and rarely interconnected (except in Nigeria), appears to be in decline in the face of the thriving supply of road transport solutions.

\section{Road transport and mobile populations}

11 Whether in cities, in the country or in interurban relations, road transport has undeniable advantages: it can serve multiple locations, uses different vehicle types, presents an abundant supply, and is an easy business opportunity which offers short term profit and a high tax potential. Since the introduction of motor vehicles in the 1930s, the car ownership rate in Africa has grown significantly, in particular since the economic liberalisation of the early 1990s (Gakenheimer, 1997). Road networks have been consolidated and now cover a large portion of national territories, after forming an emerging web on a continental or sub-regional scale. Networks of tracks often complement the main asphalted roads, allowing for motorists, coaches and motorcycles to drive to more remote villages and offering an alternative to local non-motorised transport (carts, bicycles and walking).

Gina Porter's paper (Reflections on a century of road transport developments in West Africa and their (gendered) impacts on the rural poor) aims to measure the importance of long timescales in transport-related changes. It delivers a century-wide analysis of the supply of transport and its impacts (some positive, some less so) on the rural populations of Ghana and Nigeria, in particular women. Starting from archive materials and individual surveys conducted over several decades, the author shows how the development of roads in rural areas, although it has stimulated the trade of agricultural products, has mostly driven the local populations to move closer to the roads. Porter highlights the challenging economic situation of villages that remain far away from the roads, and are of no commercial interest to the traders who travel along the main axes. Women in particular, unlike men who are more mobile and can afford to use modern transport, are increasingly isolated in some parts of Ghana and Nigeria. In other words, a brand new asphalted road might be no more than an axis that cuts through entire countries, concentrates all investment and population, and brings neglect to more remote areas with poor connections to the urban dynamics. It becomes a corridor that ignores the areas it cuts through, with travel possibilities and economic opportunity concentrated around coach stations or important junctions.

13 Further North, Benjamin Steck (West Africa facing the lack of traffic lanes. A case study: the Nouakchott-Nouadhibou road, Mauritania) shows how the creation of a new road connecting two large cities in Mauritania was affected by the contradictions of 
contemporary development. The Nouakchott/Nouadhibou road mostly serves to connect the country's two main economic centres, which are $450 \mathrm{~km}$ apart and were only connected by plane up until 2003 (Antil et Choplin, 2003). The road has stimulated trade and the national transit of goods and people, while acting as a connection on the Dakar/Casablanca international coastal axis. The road's function as a corridor is counterbalanced by the presence on its course of the national park of "Banc d'Arguin", home to the Imraguen fishing tribes whose fishing traditions are respected worldwide and who are increasingly keen to be connected to the neighbouring towns. They wish to bring carriers and wholesalers to the beaches where they unload their catch, and to move nearer to the road. Nomadic populations from inland also settle along the road and develop increasingly perennial settlements (dwellings, shops...).

The example of the Nouakchott/Nouadhibou road provides a basis for questioning the Mauritanian government's structuring and arbitration role. Who or what body is responsible for providing the necessary linkage between the growing numbers of private interests at stake - in this case the large mining groups, tradesmen, businessmen, neighbouring villages and fishermen? What is the role of public service in the provision of transport? The multiplication of stakeholders in the financing, organisation and running of transport in Africa (dedicated local agencies, donors, private international groups, national entrepreneurs), the increasing cost of private/ public partnership (PPP) processes and the multiplicity of interests have gradually driven the transport system away from its initial vocation: collective interest and territorial equity.

\section{New mobilities and inequalities}

15 The emergence of private operators is the result of economic liberalisation policies and of initiatives led businesses, migrants and civil servants to develop an alternative transport offering. Sometimes the very absence of an offering, in particular in cities where structural and sectorial adjustment programmes have weakened public-owned companies, has led to the creation of a new transport line in an isolated area or in a village. A good example is the development of "cars horaires" (coaches leaving at fixed times) in Senegal, which connect a village to the capital every hour, at the initiative of local entrepreneurs (Lombard, 2011).

Transport evolves at the initiative of neo-professionals, now exempted from state constraints, who can offer new transport modes that suit the needs and practices of urban and rural populations. Lourdes Diaz Olvera, Didier Plat, Pascal Pochet and Maïdadi Sahabana (Moto-taxis in the "transport crisis» of West and Central African cities) highlight the energy and responsiveness of moto-taxi drivers, and their great spatial mobility to meet their clients' needs. In many African cities (Calabar, Cotonou, Douala, Kampala, Lomé, Niamey), their number is constantly increasing: this shows both unemployed young people's aspiration to find an income-making activity, and demand from customers to find a cheap mode of transport to travel to the centre, between different neighbourhoods, in sandy areas, etc. Moto-taxis appear like the archetype of a successful match between demand and supply: a simple solution that offers responsiveness and flexibility in space and time. Although their security conditions are hazardous and their engines' poor combustion systems contribute to urban pollution, those two-wheel vehicles are convenient and adapted to urban and rural lifestyles, 
themselves subjected to a daily evolution depending on "ephemeral opportunities" (Montulet, 2005 : 145). Mobile phones, which are "adapted to the users' lifestyles" (Chéneau-Loquay, 2012:85), accompany and often prefigure this perpetual evolution of the supply.

People's ability to invent their own transport is sometimes related to a quest for independence from established and imposed systems. It is also characterised by an extreme differentiation between individuals or groups. The moto-taxi also symbolises the inability for many families or individuals to use any other mode of transport. On the opposite end of the spectrum, wealthy families buy scooters to give their children an alternative means of transport in often congested cities: just like luxury cars, motorbikes are a mark of social status. The gap between populations living in the same cities, regions or countries is growing - this reflects growing transformations and inequalities in access to travel and transport in Western Africa, which are already very visible today (Lombard et Ninot, 2010).

On a continent generally regarded as poor, rich people's mobility is visible but poorly documented. It shapes particular spatial relations, where expensive motorised transport allows for people to travel at will on every scale, from their opulent neighbourhood to the world, from the metropolis to the entire country. Michel Lesourd's original contribution (Mondialisation et nouvelle mobilité des élites africaines. La mobilite bourgeoise au Sud) highlights the importance of mobility as a way of life, of which the speed of movement forms a key element. In the less-densely populated rich suburbs of African cities, thanks to high levels of education or qualification combined with economic activity, populations are able to move around easily. These people are gaining much more from triumphant liberal globalisation than other, more static groups, who are often poor, marginalised and relegated to rigid tasks, activities and locations. Governments appear to be going along with the globalisation of behaviours without really trying to regulate, balance out or share access to such fundamental transformations in their relation to space.

The development of private initiatives, against a backdrop of decentralised political institutions, has complexified the landscape of transport governance. Such initiatives, often (but not exclusively) a result of the liberalisation of the 1980s, have enriched and considerably improved the supply of transport, even though they do not always favour a greater equality in access to transport and a more comprehensive territorial coverage. The populations' demands have become stronger and better organised (in the press, via bodies like consumers' associations which are still few and poorly organised we should expect to witness the apparition of the first associations for transport service users very soon): transport has become a social issue, at least in cities where the State and local authorities are expected to bring solutions. Locally or nationwide, mixed systems are being set up "where the network is complemented, and has been for a long time, by informal extensions of its own socio-technological system, and by outof-network service functionalities" (Jaglin, 2012: 52). Private initiatives (led by users, locals and professionals) innovate and introduce new modes of governance to navigate the intricacies of public regulations and popular practice: they invent a hybrid way of delivering and managing transport which doesn't go against public policies but plays along with them.

20 At a closer glance, the issue of transport governance goes beyond the national realm and also functions on a broader scale: that of the ECOWAS or the West African 
Economic and Monetary Union. Those bodies produce texts and projects aimed at harmonizing regulations on traffic, transport professions etc. A new positioning for the State is being defined on this scale, in order to respond to the demands of professionals and service users and to the necessities of equality and territorial coverage.

\section{The future of research on transport and mobility}

21 Reading this special issue brings to mind several conclusions. First of all, the diversity of case studies shouldn't stop us from developing a more global and transversal vision of the processes at work. Second, transport forms a prism through which we can grasp contemporary spatial and territorial evolutions. Finally, it is more than ever necessary to look back upon our methods of investigation.

What is it that people talk about in the periphery of Niamey, on the road between Nouakchott and Nouadhibou, or in the port of Lomé? To which extent is it legitimate to depict the mobility of rich Africans when so much reminds us of the precariousness of life on the continent? ${ }^{5}$ The multiplicity of fields of work should mean more than just a juxtaposition of particular cases. By putting those into perspective, general evolutions that cut across the whole of the contemporary world come to light - starting from the emergence in poor countries of a minority of immensely rich populations, whose mobility and transport practices echo those of American, Asian or European business elites. Western Africa is no exception in that respect: the processes observed on the continent remind us of transformations that have been observed and analysed elsewhere in the world; they sometimes even announce phenomena about to happen in other geographical areas, like for instance the dismantling of public transport services and the demultiplication of the informal sector in Northern societies. This is not to say however that Africa is uniform, and that the development of mobility is identical throughout the continent. Géraud Magrin (2010) gives a reminder of its diversity, and of the need to observe intermediary scales, the regional one for instance.

Putting the cases in this issue into perspective reveals their heuristical nature and their generalisation potential. Transport systems are worth observing because of the general and particular trends they reveal visually, materially and physically: normalisation, homogeneization (systems tend to converge, at least partly, towards global models), differentiation and growing inequalities (from the horse cart to the air-conditioned SUV). Transport is also interesting because it is evolving, shaping up and decomposing under our eyes. The changes it has undergone in the past ten years are important and undeniable: more roads, more asphalted tracks, vehicles in better condition, better access to remote locations... Africa is moving forward, it is sometimes noted ${ }^{6}$. It is researchers' responsibility to challenge the obvious in terms of transport: for instance, the model of the international corridor which is taking over all other dispatch models, including in countries with no access to the sea, for which a connection with international exchanges appears as an absolute necessity (perhaps too much so) and is therefore never questioned.

Finally, we need to situate our methodological reflection within the framework of research in social science. More than ever, we need to carry on our investigations and to multiply viewpoints. To achieve this, we should study diverse spatial scales, adopt more multidisciplinary methods (anthropology, economics, geography, demographics, statistics, engineering...), and call upon the perspectives of diverse social and 
professional groups who are keen to discuss their transportation practices and motivations. A combination of empirical approaches and theoretical reflections is the only way we can consolidate our knowledge of the joint evolution of transport and mobilities ${ }^{7}$. A phenomenological method such as the one developed on the roads of Nigeria by Adeline Masquelier (2002) reminds us of the importance of observation and experience, and stresses the part played by real life in building an understanding of practices in times of deregulation. In order to investigate the very heart of transport, we need to experiment with coaches, trucks, trains or airplanes, with the people who are travelling. An intimate perception of the phenomena, "a concrete analysis of a concrete situation" (Copans 2010: 163), even though it is doomed to be biased, is all the more necessary that transport, and therefore mobilities, are experiments: they are trials, attempts, as shown by experience-based research by Roland Pourtier (1991) or Armelle Choplin and Jerome Lombard (2010).

\section{BIBLIOGRAPHIE}

Antil A., Choplin A., 2003. Le chaînon manquant : la route Nouakchott-Nouadhibou, dernier tronçon de la transsaharienne Tanger-Dakar. Afrique contemporaine, $n^{\circ} 208$, p. 115-126.

Bruijn M. de, Van Dijk R., Foeken, D., 2001. Mobile Africa. Leiden, Brill.

Cheneau-Loquay, A., 2012. La téléphonie mobile dans les villes africaines. Une adaptation réussie au contexte local. L'Espace géographique, 1, p. 82-93.

Choplin A., Lombard J., 2010. Suivre la route". Mobilités et échanges entre Mali, Mauritanie et Sénégal. EchoGéo, 14, http://echogeo.revues.org/12127

Commission Économique pour l'Afrique, 2009. The Transport Situation in Africa. Organisation des Nations Unies, Addis Ababa, 13-15 octobre.

Copans J., 2010. Un demi-siècle d'africanisme africain. Terrains, acteurs et enjeux des sciences sociales en Afrique indépendante. Paris, Karthala.

Dawson J., Barwell I., 1993. Roads are not enough: New perspectives on rural transport planning in developing countries. London, Intermediate Technology Publications.

Dimitriou H. T., Gakenheimer R., 2011. Urban Transport In The Developing World. A Handbook of Policy and Practice. London, Edward Elgar.

Di Méo G., 1999. Géographies tranquilles du quotidien. Une analyse de la contribution des sciences sociales et de la géographie à l'étude des pratiques spatiales. Cahiers de géographie du Québec, 43 (118), p. 75-93.

Fergusson J., 2006. Global Shadows. Africa in the Neoliberal World Order. Durham, Duke University Press.

Gakenheimer R., 1997. Rapid motorization in the developing world: correlates and consequences, in Géographies de l'automobile et aménagement des territoires. Arcueil/Nanterre, INRETS/Université Paris X, p. 149-156. 
Gewald J.-B., Luning S., Van Walraven K., 2009. The Speed of Change: Motor Vehicles and People in Africa, 1890-2000. London, Brill.

Hanh H.P., Klute G. (ed.), 2007. Cultures of Migration. African Perspectives. Münster, Lit Verlag.

Hall P., McCalla R. J., Comtois C., Slack B. (ed.), 2010. Integrating Seaports and Trade Corridors. Farnham, Ashgate.

ISEMAR, 2008. Enjeux et position concurrentielle de la conteneurisation ouest-africaine. Note de synthèse $n^{\circ} 50$,www.isemar.fr

Jaglin S., 2012. Services en réseaux et ville africaines : l'universalité par d'autres voies ? L'Espace géographique, 1, p. 51-67

Kaufmann V., 2005. Mobilités et réversibilités : vers des sociétés plus fluides ?. Cahiers internationaux de sociologie, 118, p. 119-135.

Lombard J., 2011. Transports d'ici, transports d'ailleurs. Du Sénégal à l'Afrique de l'Ouest. Le Havre, Dossier d'habilitation à diriger des recherches, vol. 3, 235 p.

Lombard J., Ninot O., 2010. Connecter et intégrer : les territoires et les mutations des transports en Afrique. Bulletin de l'association des géographes français, 1, p. 69-86.

Magrin G., 2010. En attendant le centenaire... Introduction au dossier Afrique, 50 ans d'indépendance. Territoires, frontières, identités et développement. EchoGéo, 13 http:// echogeo.revues.org/12113

Mansell Prothero R., Chapman M., 2010. Circulation in Third World Countries. London, Routledge.

Masquelier A., 2002. Road Mythographies: Space, Mobility, and the Historical Imagination in Postcolonial Niger. American Ethnologist, 29, 4, p. 829-56.

Monson J., 2006. Defending the People's Railway in the Era of Liberalization: Tarazan in Southern Tanzania. Africa, 76, 1, p. 113-130.

Montulet B., 2005. Au-delà de la mobilité : des formes de mobilités. Cahiers internationaux de sociologie, 118, p. 137-159.

Porter G., 2002. Living in a Walking World: Rural Mobility and Social Equity Issues in Sub-Saharan Africa. World Development, vol. 30, n॰2, p. 285-300.

Pourtier R., 1991. L'inéluctable défi des transports. Politique Africaine, 41, p. 22-31.

Van Chi-Bonnardel R. N. 1978. Vie de relations au Sénégal. La circulation des biens ; Dakar, IFAN.

\section{NOTES}

1. In Senegal, as R. Van Chi-Bonnardel reminded us in 1978, "transport had been managed for the whole colonial period and partially after independence by French engineers from the SNCF [...] » (Van Chi-Bonnardel, 1978, p. 314).

2. SITRASS (International solidarity on transport and research in sub-Saharian Africa) is formed by research teams, experts and professionals of transport from Africa and Europe. Cf. http:// www.sitrass.org

3. At the Uppsala conference, another workshop drew attention to the African roads, their role as living spaces and their hazards and dangers (Uncertainty, Danger and the Productive Life of Risk on and alongside African Roads). 
4. Cf. J. Merlaud's film on the protest of residents living near the Mali section of the Bamako Kayes Dakar line: http://www.dailymotion.com/video/x4phtd_bamako-kayes-part1_news ; http://www.dailymotion.com/video/x4pgyq_bamako-kayes-part2_news

5. In October 2011 at the International geography festival of Saint-Dié (France) in Octobors du dernier Festival international de géographie de Saint-Dié (France), one of the contributors was reminded of the gap between his discourse on wealthy populations and endemic poverty in Africa.

6. "A significant development of transport infrastructure and services, including roads, railways, airports and seaports, has taken place" (Commission économique pour l'Afrique, 2009: 10).

7. It is fundamental to de-singularize research on transport and to open it up. A comprehensive knowledge of transport, coach stations, professionals, vehicle types is indeed useful, but it is not sufficient to grasp the part played by transport as a major economic fact and its role in society. Discussing jointly the different travelling methods and the types of users, and associating the analysis of an international corridor managed by a global logistical group with a local study of the impact of new infrastructure, can give meaning and depth to a study of transport.

\section{INDEX}

Thèmes : Sur le Champ - Sur le Terrain

\section{AUTEURS}

\section{JÉRÔME LOMBARD}

Jérôme Lombard, jerome.lombard@ird.fr, is a researcher and Professor at the IRD (Institut de Recherche pour le Développement), and a member of the PRODIG UMR research laboratory. In 2010, with Olivier Ninot, he took part in the study day on the fiftieth anniversary of African independences, organised by the Association of French geographers (« Connecter et intégrer. Les territoires et les mutations des transports en Afrique ", Bulletin de l'Association des géographes français, 2010,1) and co-edited the special issue of the journal Espaces Populations Sociétés that was dedicated to new mobilities in the South (http://eps.revues.org/index4001.htm). He has cowritten two books in 2006 and 2008: La mondialisation côté Sud (Editions de l'IRD et de l'ENS; for a review, see EchoGéo \#2: http://echogeo.revues.org/1420), and Abidjan Dakar, des villes à vendre? (L'Harmattan).

\section{OLIVIER NINOT}

Olivier Ninot, olivier.ninot@prodig.cnrs.fr, is a research engineer at the CNRS. In 2010, with Jérôme Lombard, he took part in the study day on the fiftieth anniversary of African independences organised by the Association of French geographers ( Connecter et intégrer. Les territoires et les mutations des transports en Afrique ", Bulletin de l'Association des géographes français, 2010,1) and co-edited the special issue of the journal Espaces Populations Sociétés that was dedicated to new mobilities in the South (http://eps.revues.org/index4001.htm). He has cowritten: 
- Magrin G., Ninot O., Cesaro J.D., 2011. L'Elevage pastoral au Sénégal : entre pressions spatiales et mutations commerciales. Mappemonde, $\mathrm{n}^{\circ} 101,2011-1,17 \mathrm{p}$.

- Cesaro J.D., Magrin G., Ninot O. 2010. Atlas de l'élevage au Sénégal. Paris, Prodig, 32 p. http:// hildegarde.univ-paris1.fr/elevage-senegal/ 